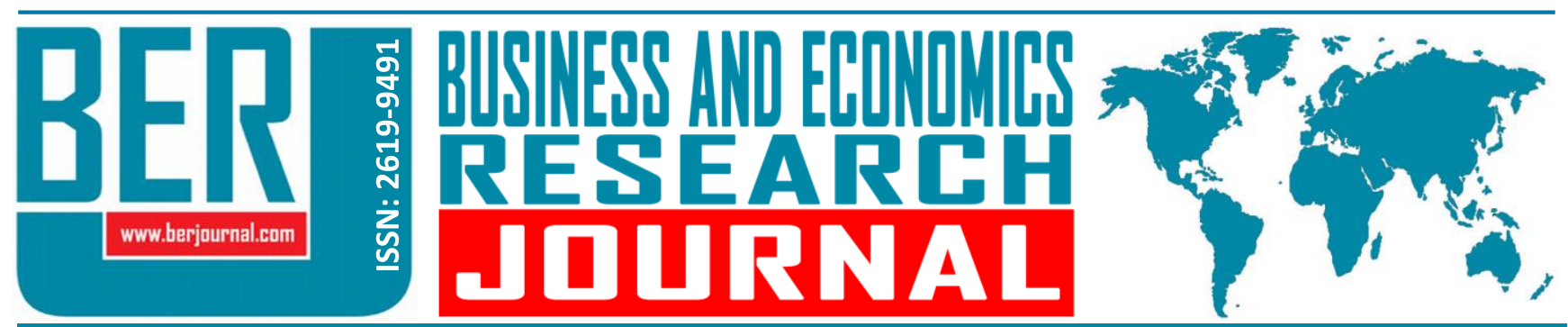

Business and Economics Research Journal Vol. 9, No. 2, 2018, pp. 431-447 doi: 10.20409/berj.2018.114

\section{İşyerlerinde Mobil Telefon Kullanım ve Bağımlılık Düzeyleri: Kamu ve Özel Sektör Çalışanları Üzerine Bir Araştırma}

\section{Huseyin Fidan ${ }^{a}$}

Öz: Sosyal ve iş hayatına önemli avantajlar getiren bilişim teknolojilerindeki ilerlemeler, fiziksel ve mental bazı sorunları beraberinde getirmektedir. Günümüzde bir hastalık olarak kabul edilen bağımlılık, teknolojik cihazların aşırı kullanımları sonucunda karşılaşılan mental bir rahatsızlıktır. Özellikle kişilerin her an yanında taşıyabildikleri mobil telefonlar, bağımlılık riskini arttırmaktadır. Firmalarda çalışanların fiziksel sağlıklarını, iş konsantrasyonlarını, ve verimliliklerini olumsuz etkileyen mobil telefonların aşırı kullanılması ve bağımılıık, iş kaybına neden olmaktadır. Bu sebeple, literatürde ihmal edilen, çalışanların işyerlerinde mobil telefon kullanımları ve bağımlılık düzeylerinin belirlenmesi, firmalar açısından önemli bir konudur. Bu çalışmada istatistiki bölge birimleri TR61 bölgesinde yer alan Burdur, Isparta ve Antalya illerinde çalışanların mobil telefon kullanım ve mobil bağımlılık düzeyleri faktör ve regresyon metotları kullanılarak analiz edilmiştir. Mobil Bağımlılık Ölçeği kullanılarak, anket yöntemi ile veriler toplanmıştır. Çalışanları arasındaki mobil bağımııık oranının \%6, mobil bağımlıık eğiliminin \%31,75 olduğunun tespit edildiği çalışma, kamu sektör çalışanları ile çalışan kadınlarda mobil bağımlılık risklerinin daha yüksek olduğunu, mobil bağımlılığın cinsiyet, yaş, gelir düzeyi farklılıklarıyla ilişkili olmadığını ortaya koymaktadır.

\section{Mobile Phone Usage and Addiction Levels in Workplaces: A Research on Public and Private Employees}

Abstract: Developments of information technologies that bring significant advantages to social life and business process bring with it physical and mental problems. Addiction, which is considered as a disease nowadays, is a mental disorder and can be seen in people as a result of overuse of technological devices. Especially mobile phones that people can carry with them at any time increase the risk of addiction. Mobile addiction, which negatively impacts the physical health, work concentration, and productivity of employees in companies, causes the job loss. Determining mobile addiction degree of employees which is neglected in the literature is an important issue for firms. In this study, mobile addiction levels of workers in Burdur, Isparta and Antalya provinces in TR61 region were analyzed by principal components and regression methods. Data were collected by the survey method by using Mobile Addiction Scale. The study found that the mobile addiction ratio among employees is $6 \%$ and the mobile addiction tendency is $31.75 \%$. The study shows that mobile addiction is higher in women and in public sector and mobile addiction is not related to gender, age and income level differences.
Anahtar Sözcükler: Mobil Bağımlılık, Teknoloji Bağımlılığı, Davranışsal Bağımlılık, Çalışanlarda Mobil Bağımlılık, Sektörel Mobil Bağımlılık

JEL: O33, L29

Geliş: 19 Şubat 2018 Düzeltme: 10 Nisan 2018 17 Nisan 2018 Kabul: 19 Nisan 2018

Keywords: Mobil Addiction, Technology Addiction, Behavioral Addiction, Employees Mobil Addiction, Sectoral Mobil Addiction

JEL: O33, L29

Received: 19 February 2018 Revised: 10 April 2018 17 April 2018

Accepted: 19 April 2018 


\section{Giriş}

Sosyolojik ve psikolojik bir konu olan bağımlılık kavramı, bir nesneye veya aktiviteye aşırı düşkünlük olarak tanımlanmakta, toplumsal yapıyı tehdit eden başıca problemler arasında görülmektedir. Toplumsal hayat standardının azalmasına sebep olan kavram genellikle eroin, esrar, alkol, sigara gibi maddesel bağımlılıklar çerçevesinde incelenmektedir. Ancak son zamanlarda kişisel aktivitelerin de bağımlılık riski taşıdığından hareket eden yaklaşımlarda yeme, uyku, egzersiz, internet gibi alışkanlıkların davranışsal bağımlıık kapsamında ele alındığı ve bu konular ile ilgili literatürde araştırmaların yapıldığı görülmektedir (Griffiths, 1995; Griffiths, 2005; Mcllwraith, Jacobvitz, Kubey ve Alexander, 1991; Turel, Serenko ve Giles, 2011; Young, 2007). Diğer taraftan toplumda hızla yayılan teknolojik cihazların sosyal yaşantıya getirdiği kolaylıklar sayesinde kullanımları hızla artmakta ve kişilerde bağımlılık riskini yükseltmektedir. Teknolojik cihaz kullanımlarına aşırı düşkünlük olarak tanımlanan teknolojik bağımlılığa sebep olan bu cihazların başında mobil telefonlar gelmektedir (Fidan, 2016).

Günümüz teknolojileri düşünüldüğünde sahip olma oranları diğerlerine göre yüksek olan mobil telefonların, işlem hızları ve kapasiteleri arttıkça, kullanım düzeyleri artmaktadır. Sunduğu imkânlar sebebiyle hızla yaygınlaşan mobil telefonlar, sosyal hayatı kolaylaştıran bir niteliğe sahiptir. Ancak birçok avantaj sunmalarına karşın mobil telefonlar, aşırı kullanımlarından kaynaklanan bazı sorunları da beraberinde getirmektedir (Bianchi ve Philips, 2005). El, bilek, baş ve göz ağrıları gibi fiziksel sorunların yanı sıra stres, depresyon, sinirlilik ve bağımlııık gibi mental sorunların oluşmasına sebep olmaktadır (Park, 2005; Toda vd., 2008). Özellikle kişilerin her an yanında taşıyabilme imkânları, internet sayesinde çok kanallı anlık iletişim sağlaması mobil telefon bağımlılığı riskini arttırmaktadır.

Mobil bağımlılık üzerine yapılan çalışmalarda genellikle anket yönteminin kullanıldığı ve geliştirilen ölçekler kullanılarak toplumsal yapı içerisindeki kesimlerin mobil bağımlılık düzeylerinin belirlenmesi ve mobil bağımlılığı etkileyen bileşenlerin tespit edilmesi hedeflenmektedir. Çalışmalarda çoğunlukla üniversite öğrencileri hedef kitle olarak seçilmektedir. Konuyla ilgili literatürde firmalar ve çalışanlar üzerine yapılan az sayıda çalışma bulunmakla birlikte bu çalışmalarda, ileri teknolojik cihazların firma faaliyetleri ve çalışanlar üzerindeki etkileri, getirdiği avantajlar çerçevesinde irdelenmektedir. Ancak sektörel düzeyde çalışanların mobil telefon kullanım ve mobil bağımlılık düzeylerinin belirlenmesi üzerine bir çalışmaya literatürde rastlanmamıştır. Bu kapsamda çalışmanın amacı, kamu ve özel sektör çalışanları arasındaki mobil bağımlılık düzeylerinin incelenmesi, sektörel analizlerin gerçekleştirilmesi ve demografik açıdan ilişkilerin belirlenmesidir. Fidan (2016) tarafından geliştirilen Mobil Bağımlılık Ölçeğinin kullanıldığı çalışma, kamu ve özel sektör çalışanlarının mobil bağımlılık düzeylerini ortaya koymaktadır.

Çalışmanın ilk bölümünde bağımlılık kavramı ve bağımlılık - teknoloji ilişkisi anlatılmıştır. İkinci bölümde davranışsal bağımlılı̆ın kavramsal tanımı ve tanı kriterleri açıklanmış, üçüncü bölümde mobil bağımlııı, mobil bağımlılık literatürü ve çalışanlar açısından mobil bağımlııı konuları anlatımıştır. Çalışmanın son bölümünde ise gerçekleştirilen saha araştırması ile ilgili hususlar anlatılmış, analiz sonuçlarına yer verilmiş, gelecek çalışmalar için öneriler sunulmuştur.

\section{Literatür Taraması}

\subsection{Bağımlııık Kavramı ve Teknoloji}

Eroin, alkol, sigara gibi maddelere aşırı düşkünlük olarak tanımlanan bağımlılık kavramı fiziksel ve/veya mental açıdan kontrol kaybı olarak nitelendirilmektedir (Young, 2007). 1987 yılında American Medical Association (AMA) tarafından bir hastalık olarak kabul edilen kavram, yapılan çalışmalar ile birlikte tekrarlamalı alışkanlıkları kapsayacak biçimde değiştirilmiştir (Leshner, 1997). Bu görüşe dayanan tanımlarda bağımlıık, hastalık riski taşıyan tekrarlamalı alışkanlıklar olarak tanımlanmaktadır (Marlatt, Baer, Donovan ve Kivlahan, 1988). Bu tanım kapsamında bağımlılık yapan maddelerin haricinde spor, yemek, uyku, televizyon, bilgisayar, internet, çevrimiçi oyun gibi davranışlarla ilgili olan alışkanlıklar, bağımlılık olarak kabul edilmiştir. Böylece kavram, madde ve davranışsal bağımlılık olmak üzere iki sınıfa ayrılarak incelenmektedir (Turel vd., 2011). 
Amerika Psikiyatri Birliği (APA), mental bozuklukların tanı kriterleri üzerine çalışmalar gerçekleştiren önemli kuruluşlardandır. Mental bozuklukların tanısal ve istatistiksel el kitabı (Diagnostic and Statistical Manual of Mental Disorders - DSM) ismiyle yayınlanan raporlarda, bilişim teknolojileri ile ilgili davranışsal bağımlııklar yeterince yer almamaktadır. APA tarafından yapılan açıklama ise yeterli klinik bulguların olmayışı sebep olarak gösterilmektedir (APA, 2013). Sadece maddesel bağımlılıkları belirlemek için tasarlanan DSM tanı kriterleri, davranışsal bağımlılıkların belirlenmesinde yetersiz kalmaktadır. Söz konusu yetersizliği vurgulayan bazı araştırmacılar, daha genel tanı kriterlerinin belirlenmesi gerektiğini ifade etmektedirler (Griffiths, 1995; Mcllwraith vd., 1991; Turel vd., 2011). Gelişen teknolojilerle birlikte ortaya çıkan yeni bağımlıık türlerine ilişkin standart tanı kriterlerinin olmaması, bu tip bağımlııkların tespit edilmesinde boşluk oluşturmaktadır (Fidan, 2016).

Bilgisayar ve internet teknolojilerinin sosyal hayat içerisinde kullanılmaya başlanmasıyla birlikte, bağımlıık kapsamında yeni araştırma konuları ortaya çıkmıştır. Teknolojik gelişmelerle birlikte görülen ve teknoloji bağımlılığı olarak nitelenen alışkanlıklar ilk olarak televizyon ile incelenmiştir (Smith, 1986). Teknolojik cihazların kullanımına aşırı düşkünlük olarak tanımlanan teknoloji bağımlılı̆ı (Turel vd., 2011), toplumsal yapıyı etkileyen sorunlardan biri olarak görülmektedir (Young, 2007). Literatürdeki genel görüş internet, bilgisayar, bilgisayar oyunu, çevrimiçi oyun, mobil telefon gibi teknolojik alışkanlıkların davranışsal bağımlılık kapsamında incelenmesi yönündedir (Fidan, 2016; Griffiths, 1995; Griffiths, 2005; Mcllwraith vd., 1991; Shaffer vd., 2004; Turel vd., 2011). Özellikle internet tabanlı sistemlerin gelişmesi, toplumda bağımlıık seviyesinin artmasına neden olmaktadır (Reid ve Reid, 2007). Son yıllarda internetin kullanılabildiği mobil telefonların geliştirilmesi, bağımlılık kapsamında toplumsal yapıyı tehdit eden sorunların başında görülmektedir (Fidan, 2016). Bu bağlamda, toplumda yaygın kullanım imkânı bulan mobil telefonların bağımlılık analizlerinin yapılması önem arz etmektedir.

\subsection{Davranışsal Bağımlılık ve Tanı Kriterleri}

Son yıllarda maddesel alışkanlıklardan kaynaklanan bağımlılıklar ile davranışsal bağımlılıkların sebep olduğu nörobiyolojik etkilerin benzer olduğuna dair bulgularda artış gözlenmektedir. Bu çalışmalara göre maddesel ve davranışsal bağımlılık yapan tüm alışkanlıklar beynin aynı bölgesini etkilemektedir (Knutson, Rick, Wimmer, Prelec, ve Loewenstein, 2007; Wang, Volkow, Thanos ve Fowler, 2004). Davranışsal bağımlılık kapsamında araştırılan konular çeşitlilik göstermektedir. Uyku, yeme, cinsel ilişki, teknoloji, çalışma, egzersiz gibi alışkanlık deseni oluşturan aktiviteler davranışsal bağımlılığın araştırma konuları arasındadır (Karim ve Chaudhri, 2012). Aynı zamanda gelişen bilişim teknolojilerinin yaygınlaştırdığı elektronik cihazlar, bağımlılık noktasında toplumda önemli riskler oluşturmaktadır (Griffiths, 2005; iHH, 2015). İnternet bağımlılı̆ı, çevrimiçi oyun bağımlılığı, sosyal medya bağımlılığı, mobil telefon bağımlılığı gibi konular, teknoloji bağımlılığı çerçevesinde incelenen davranışsal bağımlılıklardır.

DSM tarafından yeterince dikkate alınmayan davranışsal bağımlılık kavramı son yıllarda literatürde dikkat çeken konular arasındadır. Farklı yaklaşımlar nedeniyle davranışsal bağımlılık tanı kriterleri ile ilgili literatürde de bir uzlaşı bulunmamaktadır. Araştırmacılar tarafından çeşitli kriterler kullanarak davranışsal bağımlıık tanısının konulması amaçlamaktadır. Bu çerçevede belirginlik, duygusal değişim, tolerans, uzaklaşım, çatışma, tekrarlama belirtileri, literatürde genel olarak kullanılan davranışsal bağımlılık tanı kriterleridir (Choliz, 2012; Fidan, 2016; Griffiths, 1995; Griffiths, 2005; Kwon vd., 2013; Shaffer vd., 2004; Sultan, 2014; Turel vd., 2011). Davranışsal bağımlııı ile ilgili tanı kriterlerinin açıklamaları aşağıda verilmiştir.

Belirginlik: Bazı alışkanlıkların kişinin sosyal hayatını olumsuz etkileyecek derecede olmasıdır. Uyku bağımlısı olan kişinin, kendisi için önemli olan randevularına dahi gitmemesi ve sigara alışkanlığı olan bir kişinin sigara içememesi nedeniyle sinemaya gitmemesi örnek olarak verilebilir. Kişi için uyumak veya sigara içmek, diğer aktivitelere göre daha önemli hale gelmiştir.

Duygusal değişim: Kişinin, alışkanlıklarına değişik zamanlarda farklı ruhsal yaklaşımlarda bulunmasıdır. Örneğin egzersiz alışkanlığı olan kişi, çok arzulu egzersiz yapma isteği ertesi gün değişebilir, kendisinin ne yaptığını sorgulayabilir ve egzersizden nefret etme derecesine gelebilir. 
Tolerans: Alışkanlığa sebep olan aktivitenin giderek artmasıdır. Yeme alışkanlığı olan kişinin, yemekten aldığı haz sebebiyle zamanla yeme miktarını ve süresini arttırmasıdır.

Uzaklaşım: Aktivitenin azaltılması veya terk edilmesi ile kişinin fiziksel ve mental problemler yaşamasıdır. Yeme alışkanlığını terk eden kişinin titreme, huzursuzluk, sinirlilik, halsizlik, mutsuzluk, depresyon gibi sorunlar yaşaması örnek olarak verilebilir.

Çatışma: Alışkanlığı sebebiyle kişinin çatışma yaşamasıdır. Çatışma kendi iç dünyasında yaşanabildiği gibi çevresindeki insanlarla da yaşanabilir. Uyku bağımlılığı olan kişinin, ailesi ve çocukları ile sorunlar yaşaması, bu alışkanlığı sebebiyle kendisini yargılamasıdır.

Tekrarlama: Azaltılan veya terk edilen bir alışkanlığın zamanla eski kullanım düzeyine ulaşmasıdır. Sigara kullanımını terk eden bir kişinin, bir zaman sonra sigara içmeye yeniden başlaması örnek olarak verilebilir.

Yukarda anlatılan tanı kriterleri kullanılarak davranışsal bağımlılıkların belirlenmesine yönelik bazı çalışmalar gerçekleştirilmiştir. Teknoloji bağımlılı̆ı, davranışsal bağımlıık kapsamında incelenen bir konudur (Fidan, 2016; Griffiths, 1995; Shaffer vd., 2004). Kumar makinaları (Griffiths, 1995), televizyon (Mcllwraith vd., 1991), internet (Young, 2007), çevrimiçi oyun (Ko vd., 2009) ve mobil telefon (Fidan, 2016) alışkanlıkları bu kapsamda araştırılan konular arasındadır. Son on yılda ise akıllı telefonlar ile ilgili çalışmalarda yoğunluk görülmektedir. Fidan'a (2016) göre mobil telefonların işlem kapasitelerinin artması, internet kullanım imkânı sunması, uygulama yüklenebilmesi ve rahatlıkla taşınabilmesi, mobil telefonların bağımlılık risklerinin diğer teknolojik cihazlara göre daha fazla olmasına sebep olmaktadır.

\subsection{Mobil Bağımlılık}

Bir bilgisayarla yapılabilecek işlemlerin gerçekleştirilebildiği cihazlar olan mobil telefonlar, her geçen gün kullanımları, hız ve işlem kapasiteleri artmaktadır. Geliştirilen uygulamalar sayesinde sosyal hayatı kolaylaştıran mobil telefonlar, sesli iletişim amacıyla tasarlanmalarına rağmen, sunduğu imkânlar sayesinde bu amacın dışına çıkan bir teknoloji olarak sosyal hayatta yerini almıştır. Günümüzde artık ihtiyaçtan çok bir zorunluluk haline gelmiştir (Fidan, 2016). Mark Andreessen'e göre dünya yaşamının başladığı andan bu yana gerçekleştirilen en heyecan verici buluş niteliğindedir (CNBC, 2011). Mobil telefonlar ile 1983 yılında ilk görüşmelerin başladığını ifade eden Miller (2012), mobil devrimin 1994 yılında IBM firmasının ürettiği akıllı telefonlarla başladığını vurgulamaktadır. Uygulama yüklenmesine izin veren bu telefonlar günümüzde insanların vazgeçemedikleri bir cihaz haline gelmiştir.

Sosyal hayattaki gereksinimleri karşılayabilecek işlem kapasitesine sahip olan mobil telefonlar, dünyada geniş bir kullanım alanına kavuşmuştur. 2014 yılı itibariyle dünyada dört milyar kullanıcının olduğu mobil telefonların 2019 yılında beş milyar kullanıııya ulaşacağı tahmin edilmektedir (Statista, 2016). Fitchard'a (2013) göre 2019 yılında dünya nüfusunun \%60'ı mobil telefona sahip olacaktır. Gelişmiş ülkelerde mobil telefon kullanım oranlarının daha yüksek olduğunu belirten ITU (2015), Avrupa'da bu oranın \%78 ve Türkiye'de \%95 olduğunu belirtmiştir. TÜiK'e (Türkiye İstatistik Kurumu) göre 2015 itibariyle bu oran \%96,8 ve 2016 'da \%96,9'dur. Oranlardan anlaşılacağı üzere mobil telefon kullanım düzeyleri oldukça yüksek olup, ilerleyen yıllarda bu oranların yükseleceği ifade edilebilir.

Birçok avantajlar sunan mobil telefonlar, kullanımlarından kaynaklanan bazı sorunları da beraberinde getirmektedir (Bianchi ve Philips, 2005). Fiziksel ve mental olarak iki grup altında toplanan bu sorunlar, kişilerin yaşam standartlarını olumsuz yönde etkilemektedir. Baş, boyun, sırt, el ve kol ağrıları fiziksel sorunlar arasında yer alırken, depresyon, anksiyete, stres ve bağımlılık mental sorunlar arasında görülmektedir (Park, 2005; Toda vd., 2008). Günlük yaşantı içerisinde sürekli taşınabilir olması, mobil telefonlardan kaynaklanan bu sorunların artmasına neden olmaktadır. Özellikle genç nüfus arasında mobil telefon kullanımının yüksek olduğu düşünüldüğünde ilerleyen yıllarda sağlık problemlerinin yüksek olduğu bir toplum yapısının oluşmasına sebep olacak kadar ciddi bir konudur.

Mobil telefonların yaygınlaşması ile mobil bağımlılık ile ilgili çalışmaların 2000'li yıllarda başladığı, kavramın mobil bağımlıık veya nomofobi olarak nitelendiği görülmektedir (Billieux, Vander-Linden ve Rochat, 
2008; Kwon vd., 2013). Yapılan araştırmalarda anket yöntemi kullanılmakta ve genellikle çalışmalar ölçek oluşturma amacını taşımaktadır. Çalışmalarda hedef kitle olarak üniversite öğrencilerinin seçildiği çalışmalara sık rastlanmakta, iş hayatına ve çalışanlara yönelik araştırmaların ihmal edildiği görülmektedir.

\subsection{Mobil Bağımlılıkla İlgili Çalışmalar}

DSM kriterlerine dayanan bağımlılık ile ilgili çalışmalarda tolerans, uzaklaşım, kurtulma arzusu, çabalama, fedakârlık ve vazgeçememe gibi tanı kriterleri kullanılmaktadır (APA, 2013). Mobil bağımlılıkların belirlenmesinde, maddesel bağımlııkların belirlenebilmesi için kullanılan bu tanı kriterlerinin kullanılabileceğini savunan bazı çalışmalar gerçekleştirilmiştir. Mobil telefon bağımlıı̆ı̆ının, teknolojik bağımlılığın bir biçimi olduğunu vurgulayan Yen vd. (2009), gerçekleştirdikleri anket uygulamasında katılımcıların \%48'inin söz konusu DSM kriterlerinden en az birine sahip olduklarını belirlemişlerdir. Merlo, Stone ve Bibbey (2013), DSM kriterlerine göre bir mobil bağımlılık ölçeği geliştirmişlerdir. Choliz (2012), mobil bağımlılığın belirlenmesinde başlıca kriterlerin tolerans, kontrol eksikliği ve yoksunluk olduğunu belirlemiştir.

DSM kriterlerinin maddesel bağımlııkları belirleme amacını taşıdığını ve davranışsal bağımlııkların belirlenmesinde bu kriterlerin yetersiz kalacağını ileri süren yaklaşımlar da söz konusudur. DSM kriterlerine de yer veren bu yaklaşıma göre davranışsal bağımlııkla ilgili belirginlik, tolerans, çatışma, duygusal değişim, uzaklaşım, tekrarlama olmak üzere altı kriterin analizlerde yer alması gerektiği belirtilmektedir (Fidan, 2016; Griffiths, 1995; Griffits, 2005; Kuss, Shorter, Rooij, Griffiths ve Schoenmakers, 2013; Kwon, vd., 2013; Turel vd., 2011). Davranışsal bağımlılık çerçevesinde mobil bağımlılığı inceleyen çalışmalara rastlamak mümkündür. Kwon vd. (2013), bu kriterler arasındaki tolerans ve uzaklaşım kriterlerinin mobil bağımlılık ile ilişkisini ortaya koymuştur. Billieux, Maurage, Fernandez, Kuss ve Griffiths (2015), davranışsal bağımlılık kriterlerinin gözlemsel açıdan yeterince desteklenmediğini belirterek, mobil bağımlılık tanısının tolerans, uzaklaşım belirtileri ve kontrol kaybı kriterleri ile konulabileceğini tespit etmişlerdir. Hong, Chiu ve Huang (2012), Salehan ve Nagehban (2013) ve Sultan (2014), mobil bağımlılığı davranışsal bağımlılık çerçevesinde incelemişler, ayrıca sosyal medya uygulamalarının mobil bağımlılık üzerinde etkin bir faktör olduğunu belirlemişlerdir. Mobil bağımlılığı davranışsal bağımlıık çerçevesinde ele alan bir başka çalışmada Fidan (2016), bileşenler modeli çerçevesinde bir mobil bağımlılık ölçeği geliştirmiş, mobil bağımlılığın tolerans, tekrarlama, belirginlik ve uzaklaşım belirtileri ile ilişkili olduğunu tespit etmiştir. Ayrıca çalışmada, mobil internet eğiliminin, mobil bağımlılığı etkileyen önemli bir faktör olarak analizlerde kullanılması gerektiği vurgulanmıştır.

\section{5. Çalışan Kesim, Teknoloji ve Mobil Bağımlılık}

Firmalarda yaşanan teknolojik gelişmeler, organizasyon yapısında köklü değişimler ortaya çıkarmaktadır. Sektörel yapıda bilişim teknolojileri kullanılmaya başlanması ile firmalar arası rekabetin artmasına sebep olan bu gelişmeler, firmaların bilişim teknolojilerine geçişini zorunluluk haline getirmektedir (Fidan, 2017). Bu sebeple firmalar rekabet güçlerinin zayıflamaması ve iş süreçleri etkinliklerinin artması gibi nedenlerle bilgisayar, veri tabanları, yazılımlar, web sayfaları, bulut teknolojiler ve mobil teknolojiler gibi birçok sisteme yatırım yapmaktadırlar.

Akıllı mobil teknolojiler aracılığıyla çalışanların işyeri dışından uzakta çalışmaları organizasyonların esnek çalışma ortamı oluşturmak, bu sayede maliyetleri azaltmak ve verimliliği arttırmak için tercih ettikleri bir yöntemdir (Lewis ve Cooper, 2005). Literatürde, işyerlerinde ileri teknoloji kullanımlarının organizasyon faaliyetlerinin etkinliğini arttırdığı yönünde görüş birliği bulunmaktadır. Ancak konuyu çalışanlar yönünden inceleyen çalışmalarda aynı görüş birliğinden söz etmek mümkün değildir. Bazı araştırmalar, mobil teknolojiler sayesinde çalışanlara sunulan ortamın çalışanların stres ve yorgunluklarını azalttığı ve bu sayede iş verimliliklerinin yükseldiğini ileri sürmektedir (Butler, Asaheim ve Williams, 2007; Wheatley, 2012). Diğer taraftan bazı araştırmacılara göre, işyerinde akıllı cihaz kullanımları çalışanlar üzerinde kas ve iskelet problemlerinin yanı sıra sosyal çatışma sebebiyle, huzursuzluk, mutsuzluk gibi sosyolojik ve psikolojik sorunlar oluşturmaktadır (Hilbrecht, Shaw, Johnson ve Andrey, 2008; Sang, Gyi ve Haslam, 2010). Yihong, Raubal ve Liu (2010), işyerlerinde mobil telefon kullanımlarının, çalışanların iş konsantrasyonlarını olumsuz etkilediğini ve buna bağlı olarak iş verimliliğinde azalmaya sebep olduğunu ifade etmişlerdir. Zimmerman (2017) ise mobil 
telefona bağımlı hale gelinmesi durumunda, çalışanlarda oluşabilecek dikkat dağınıklığının iş hayatının olumsuz etkileneceğini vurgulamaktadır. Pitichat (2013) ise işyerlerinde mobil telefon kullanımlarının verimliliği düşürdüğü gerekçesi ile yasaklanmasının yerine kontrollü biçimde izin verilmesinin uygun bir yaklaşım olacağını savunmuştur. Bu şekilde çalışanların iş memnuniyetlerinin artacağı, buna bağlı olarak iş verimliliklerinin yükseleceğini belirtmiştir. Verimlilik üzerine bir başka çalışmayı Pakistan'da 200 çalışan ile gerçekleştiren Wahla ve Awan (2014), işyerlerinde mobil telefon kullanımlarının çalışan verimliliğini azalttığı yönündeki düşüncelerin sektörlere göre değişiklik gösterdiğini belirlemiştir. Çalışmaya göre üretim sektöründe çalışanlar mobil telefonun iş süreçlerini olumsuz etkilediğini düşünürken, hizmet sektöründe çalışanlar verimliliği arttırdığını düşünmektedirler.

Mobil teknolojiler sayesinde, çalışanlar tatilde dahi işten kopamamakta ve işlerini mobil telefonlar üzerinden takip etmektedirler. İnsan kaynakları firması olan Randstad'ın (2015) küresel düzeyde gerçekleştirdiği çalışma raporu, çalışanların \%47'sinin tatile gittiklerinde iş yaşantılarında neler olduğunu mobil telefondan takip ettiklerini, söz konusu eğilimin genç yaşta olanlarda daha yüksek olduğunu ortaya koymaktadır. Aynı raporda, işverenlerin \%57'sinin mesai dışında dahi çalışanlarına ulaşabilme isteğinin olduğu vurgulanmaktadır (Randstad, 2015). Bu durum çalışanlar arasında mobil bağımlılık riskinin artması anlamına geldiği gibi, mobil teknolojilerin çalışma bağımlılığı gibi daha farklı bağımlııklara da yol açabileceği anlamına gelmektedir. The Economist'e (2010) göre iş yerlerinde telefon kullanımının, iş hayatı ve güncel hayat ayrımının yapılamamasına yol açarak kişilerin stres düzeyini arttırmaktadır. Ayrıca mobil telefonların her an yanında taşınması çalışanları gerçeklikten uzaklaştırmakta ve iş yerlerindeki ilişkileri olumsuz etkilemektedir (Bozeman, 2010).

İşyerlerinde mobil telefon kullanımları ile ilgili çalışmalarda incelenen bir diğer konu, mobil telefon kullanımlarında yaşanan iş kayıpları üzerinedir. İşyerlerinde kişisel mobil telefonlarını kullanan çalışanlar genellikle kendi özel işleri için kullanmakta, gün içerisinde en az bir saatlerini iş dışı aktivitelerle geçirmektedirler (Vitak, Crouese ve Larose, 2011). CareerBuilder'ın (2016) araştırmasına göre işyerlerinde iş dışı aktivitelerle günde kişi başı bir veya iki saatlik iş kaybı yaşanmakta, iş kaybının nedenleri arasında \%55 ile kişisel amaçlı mobil telefon kullanımları, ilk sırada gelmektedir. Fortune'a (2017) göre işyerlerinde mobil telefon kullanımlarından dolayı bir iş gününde yaşanan iş kaybı kişi başı ortalama 56 dakikadır. Başka bir araştırmaya göre, bir haftalık çalışma süresi içerisinde çalışanlar 8 saatlerini iş dışı aktivitelerle geçirmekte, bu aktivitelerin başında mobil telefonlar ilk sırada gelmektedir (OfficeTeam, 2017). Aynı araştırmada çalışanların iş yerlerinde kişisel işlemleri için mobil telefon kullanım sürelerinin günde ortalama 48 dakika olduğu, bu sürenin çalışanın yaş seviyesi azaldıkça arttığı belirtilmektedir.

Mobil telefonların iş yerlerinde kullanımlarına yönelik çalışmalar incelendiğinde konunun firmalar ve çalışanlar çerçevesinde incelendiği, araştırmalarda genellikle verimlilik ve iş kayıpları üzerine yoğunlaşıldığı görülmektedir. Günümüz teknolojik gelişmeleri, firmaların teknolojik organizasyon yapısı ve sosyal yapıdaki değişimler, güncel hayatta ve işyerlerinde çalışanların mobil teknolojileri kullanma eğilimlerini arttırmaktadır (Zielinski, 2012). Ancak çalışma hayatında mobil teknolojilerin kullanımı ile ilgili üzerinde durulması gereken ve önlem alınması gereken en önemli konu çalışanların mobil bağımlı hale gelmeleridir (Pitichat, 2013). Bu bağlamda çalışanların mobil bağımlılık düzeylerinin ve mobil telefon kullanım sürelerinin araştırılması, hem firmalar hem de çalışanlar açısından önem arz etmektedir.

\section{Yöntem}

\subsection{Amaç ve Kapsam}

Çalışmada, kamu ve özel sektör çalışanlarının işyerlerinde mobil telefon kullanım ve mobil bağımlılık düzeylerinin belirlenmesi amaçlanmaktadır. Bu çerçevede çalışma, istatistiki bölge birimleri üçüncü düzeydeki TR61 bölgesinde yer alan Burdur, Isparta ve Antalya illerindeki kamu ve özel sektör çalışanlarının mobil bağımlııı ile ilgili görüşlerini kapsamaktadır. 


\subsection{Mobil Bağımlılık Ölçeği}

Mobil bağımlılığı belirleyen tanı kriterleri için Fidan (2016) tarafından geliştirilen ve geçerliliği kanıtlanan Mobil Bağımlılık Ölçeği kullanılmıştır. Söz konusu ölçekte altı kriterin yanı sıra mobil internet eğilimi tanı kriteri olarak kullanılmıştır. Ancak ölçeğin geçerlilik analizi sonuçlarına göre çatışma ve duygusal değişim kriterlerinin mobil bağımlılık ile anlamlıığı belirlenememiştir. Fidan'a (2016) göre mobil bağımlılık tanısı konulabilmesi için tolerans, tekrarlama, uzaklaşım ve belirginlik kriterlerinin yanı sıra mobil internet eğiliminin de analize dahil edilmesi gerekir. Bu bağlamda kullanılan ölçek değişkenleri Tablo 1'de verilmiştir.

Tablo 1. Mobil Bağımlılık Ölçeği

\begin{tabular}{|c|c|c|}
\hline Tanı kriteri & Değişken & Anket sorusu \\
\hline \multirow{4}{*}{$\begin{array}{l}\text { Belirginlik } \\
\quad \text { (BEL) }\end{array}$} & Bel1 & Mobil telefon kullanırken planladığım işleri unuturum. \\
\hline & Bel2 & Mobil telefon kullanmamı engelleyen işler bana sıkıcı gelir. \\
\hline & Bel3 & $\begin{array}{l}\text { Mobil telefon kullanmazken, telefonda daha önce yaptığım işlemleri } \\
\text { düşünürüm. }\end{array}$ \\
\hline & Bel4 & Mobil telefon kullanmam bana her şeyden daha cazip gelir. \\
\hline \multirow{4}{*}{$\begin{array}{l}\text { Tolerans } \\
\text { (TOL) }\end{array}$} & Tol1 & $\begin{array}{l}\text { Zaman geçtikçe mobil telefonumu daha sık kontrol etme gereği } \\
\text { hissediyorum. }\end{array}$ \\
\hline & Tol2 & Mobil telefonumu planladığımdan daha uzun süre kullanırım. \\
\hline & Tol3 & $\begin{array}{l}\text { Mobil telefonu kullandıktan hemen sonra tekrar kontrol etme gereği } \\
\text { hissederim. }\end{array}$ \\
\hline & Tol4 & Mobil telefonumu kullandığım sürenin giderek arttığını düşünüyorum. \\
\hline \multirow{4}{*}{$\begin{array}{l}\text { Uzaklaşım } \\
\qquad \text { (UZ) }\end{array}$} & Uz1 & Mobil telefonum olmadan hayat boş gelir. \\
\hline & Uz2 & Mobil telefon kullanamadığımda huysuz ve sinirli hissederim. \\
\hline & Uz3 & $\begin{array}{l}\text { Mobil telefonum yanımda olmadığında onunla yapacağım işlemleri } \\
\text { düşünürüm. }\end{array}$ \\
\hline & Uz4 & Bilek ve boyun ağrılarımın sebebi olarak mobil telefonumu görüyorum. \\
\hline \multirow{4}{*}{$\begin{array}{l}\text { Tekrarlama } \\
\text { (TEK) }\end{array}$} & Tek1 & Mobil telefon kullanımımı azaltıyorum ama tekrar artıyor. \\
\hline & Tek2 & Mobil telefonla işim bitse dahi kendimi "Biraz daha " derken buluyorum. \\
\hline & Tek3 & Mobil telefon kullanımını bırakmak için çabalıyorum. \\
\hline & Tek4 & $\begin{array}{l}\text { Uzun süre mobil telefon kullanmasam dahi, tekrar başladığımda aşırı } \\
\text { kullanımım devam eder. }\end{array}$ \\
\hline \multirow{4}{*}{$\begin{array}{c}\text { Mobil } \\
\text { İnternet } \\
\text { Eğilimi (INT) }\end{array}$} & Int1 & $\begin{array}{l}\text { İnternet kullanmam gereken işlemlerimi mobil telefonumla } \\
\text { gerçekleştiririm. }\end{array}$ \\
\hline & Int2 & $\begin{array}{l}\text { İnternete giremesem mobil telefonun anlamının olmadığını } \\
\text { düşünüyorum. }\end{array}$ \\
\hline & int3 & İnternet, mobil telefon kullandığım süreyi arttırıyor. \\
\hline & Int4 & $\begin{array}{l}\text { Mobil telefonumu elime aldığımda hemen internet bağlantısını kontrol } \\
\text { ederim }\end{array}$ \\
\hline
\end{tabular}

Kaynak: Fidan 2016, s. 444

\subsection{Verilerin Toplanması ve Veri Seti}

Hazırlanan anket soruları ile Burdur il merkezinde 20 kişilik bir gruba pilot uygulama gerçekleştirilmiştir. Pilot uygulama sonrasında anket soruların anlaşılması noktasında bir sorun ile karşılaşılmamıştır. Pilot uygulama esnasında işyerlerinde çalışanların isteksizlikleri gözlenmiştir. Bunun üzerine işyeri çalışma düzenini etkilememek, çalışanların anket sorularına daha sağlıklı cevap verebilmelerini sağlamak ve pilot uygulamada karşılaşılan isteksizliklerin önüne geçmek için gerçek uygulamada iş yerlerine gidilmemiş̧ir. Anket uygulaması, istatistiki bölge birimleri üçüncü düzeyde yer alan TR61 bölgesindeki Burdur, Isparta ve Antalya il merkezlerinde, insanların yoğun olarak bulunduğu kamuya açık alanlarda yüz yüze görüşme ile 2017 yılı Eylül ve Ekim aylarında gerçekleştirilmiştir. Verilerin toplanmasında katılımcılar gönüllülük esasına göre rastgele seçilmiştir. 
TR61 bölgesinde yer alan illerin nüfus sayıları, istihdam oranları ve istihdam sayıları Tablo 2'de sunulmuştur. Bu tabloya göre Burdur, Isparta ve Antalya illerindeki, kamu ve özel sektör çalışan sayılarından oluşan evren büyüklüğü 1615772 olarak tespit edilmiştir. Evren büyüklüğünün 500.000 üzeri olması halinde \%95 güven aralığı ve 0,05 hata oranında örneklem büyüklüğünün en az 384 olması gerekmektedir (Yazıcıŏlu ve Erdoğan, 2004). Hatalı doldurulan anketler ve kapsam dışı katılımlar olabileceği düşünülerek uygulanacak anket sayısı 450 olarak belirlenmiştir. Bu anket sayılarının illere göre dağılımı illerin istihdam oranlarına göre hesaplanmıştır. Tablo 2' de görüldüğü üzere Burdur 41, Isparta 61 ve Antalya 348 olmak üzere il merkezlerinde toplam 450 kişiye anket uygulanmıştır. Anket uygulamasına gönüllü olarak katılan kişilerden bazılarının öğrenci (17 anket), işsiz (14 anket), emekli ( 9 anket) ve mobil telefona sahip olmayan ( 3 anket) katılımcılar olduğu görülmüş, 7 anketin hatalı düzenlendiği belirlenmiş ve toplam 50 anket analizden çıkarılmış, veri seti 400 katılımcıdan elde edilen veriler ile oluşturulmuştur.

Tablo 2. Veri Seti Bilgileri

\begin{tabular}{|c|c|c|c|c|}
\hline & Burdur & Isparta & Antalya & Toplam \\
\hline Nüfus $(2016)^{a}$ & 261401 & 427324 & 2328555 & 3017280 \\
\hline İstihdam oranı (\%) & 56,3 & 51,6 & 53,6 & - \\
\hline Çalışan sayısı (kişi) & 147168 & 220499 & 1248105 & 1615772 \\
\hline Uygulanacak anket & 41 & 61 & 348 & 450 \\
\hline Geçersiz anket & 0 & 4 & 46 & 50 \\
\hline Geçerli anket & 41 & 57 & 302 & 400 \\
\hline
\end{tabular}

\subsection{Verilerin Analizi}

Veri toplama aracı olan Mobil Bağımlılık Ölçeği ile elde edilen veriler Excel programına aktarılmış ve metinsel içerikli demografik değişkenlerin sayısallaştırılması Excel'de gerçekleştirilmiştir. Analiz için SPSS for Windows 15.0 paket programına aktarılan verilerin dağılımları kontrol edilmiştir. Değişkenlerin çarpıklık ve basıklık değerlerinin $-1,5$ ile $+1,5$ arasında olduğu gözlenmiştir. Tabachnick ve Fidell'e (2013) göre bu aralık, verilerin normal dağılıma sahip olduğunun göstergesidir.

Değişkenlerin güvenirlik değeri CronBach's Alpha ile hesaplanmış ve güvenirlik değerini azaltan Uz4 ile Tek4 değişkenleri analizden çıkarılmışır. Bu değişkenlerin analiz dışı bırakılmasıyla CronBach's Alpha değerinin 0,876 olduğu belirlenmiştir. Faktörleşme için verilerin yeterliliğini ortaya koyan Kaiser-Meyer-Ohlin (KMO) testi ve küresellik (Barlett) testi sonuçları Tablo 3'te verilmiştir. KMO değerinin 0,886 olması örneklem büyüklüğünün yeterli olduğunu, küresellik testi sonucunda $p<0,05$ olması, korelasyon matrisinin birim matristen farklı olduğunu göstermektedir. Bu testlerin sonuçlarına göre, elde edilen verilerin faktörleşebileceği tespit edilmiştir (Kootstra, 2004; Polat, 2012).

Tablo 3. KMO ve Barlett Test Sonuçları

\begin{tabular}{llr}
\hline \multicolumn{2}{l|}{ Kaiser-Meyer-Olkin (KMO) değeri } &, 886 \\
\hline Bartlett Testi & Ki-kare & 2552,618 \\
\cline { 2 - 3 } & Serbestlik (df) & 153 \\
\cline { 2 - 3 } & Anlamlılık (p) &, 000 \\
\hline
\end{tabular}




\section{Analiz Bulguları}

\subsection{Tanımlayıcı Bulgular}

Araştırmaya katılan 400 çalışandan 143'ü 15-30, 133'ü 31-45 yaş aralığında ve 124 tanesi 45 yaş üzerindedir. Katılımcıların \%27'si illkokul, \%35'i Ortaokul, \%27'si Lise ve \%10'u üniversite mezunu olup, $\% 31,5^{\prime} i$, kamu, \%68,5'i özel sektörde çalışmaktadır. Çalışanların \%54,8'i kadın olup özel sektördeki oranı $\% 40,5$ ve kamu sektöründeki oranı \%14,3 tür. Katılımcıların gelir düzeyi aralıklarını gösteren Tablo 4 incelendiğinde katılımcıların 0-2500 TL aralığında ücret aldığı görülmektedir. Kamu sektöründe 0-1500 TL ücret aralığında çalışan olmadığı, gelir seviyesi arttığında özel sektörde çalışan kişi oranın azaldığı dikkat çekmektedir.

Tablo 4. Sektör - Gelir Çapraz Tablosu

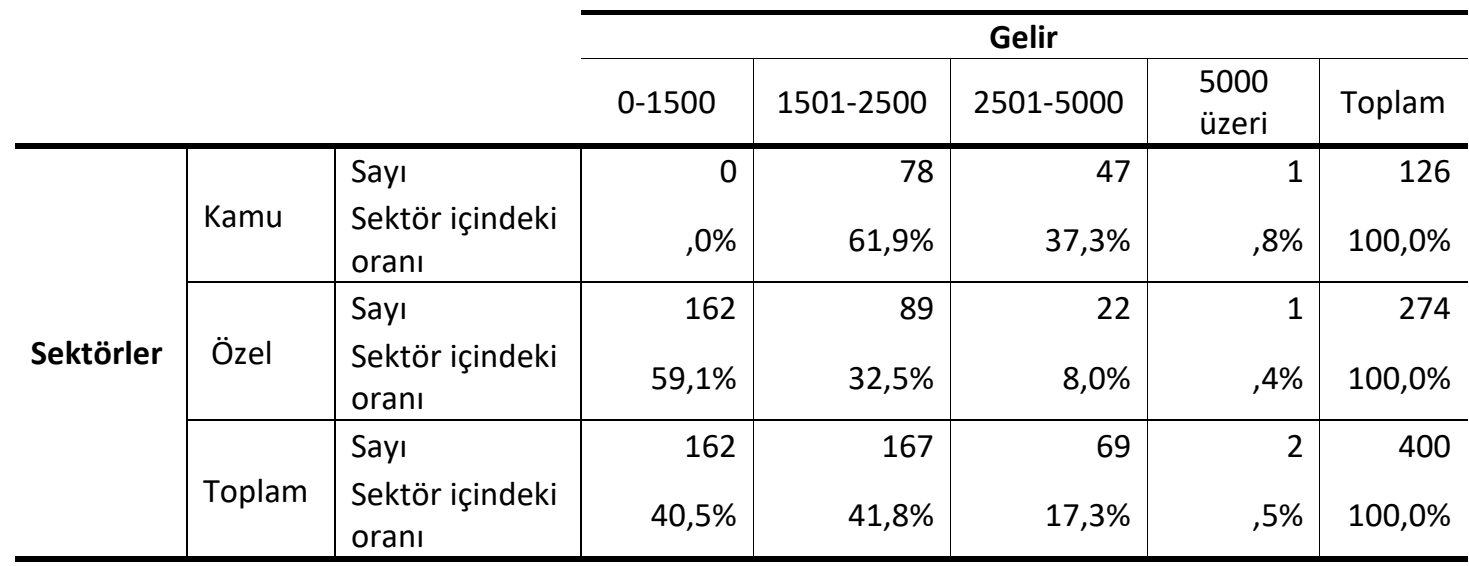

Katılımcıların eğitim seviyelerinin verildiği Tablo 5 incelendiğinde eğitim düzeyindeki artış ile birlikte kamu sektöründe çalışan kişi oranının arttığı gözlenmektedir. Eğitim seviyesi düşük olan kişilerin genellikle özel sektörde istihdam edildiği anlamına gelmektedir. Benzer durum sektör-yaş oranlarının verildiği Tablo 6 'da da söz konusudur. Yaş düzeyi azaldıkça özel sektörde çalışanların oranı artmaktadır.

Tablo 5. Sektör - Eğitim Çapraz Tablosu

\begin{tabular}{|c|c|c|c|c|c|c|c|c|}
\hline & & & & & & & & \\
\hline & & & \multicolumn{6}{|c|}{ Eğitim seviyesi } \\
\hline & & & ilkokul & Ortaokul & Lise & Üniversite & $\begin{array}{l}\text { Lisans } \\
\text { üstü }\end{array}$ & Toplam \\
\hline \multirow{6}{*}{ Sektörler } & \multirow{2}{*}{ Kamu } & Sayı & 12 & 43 & 47 & 24 & 0 & 126 \\
\hline & & \% sektör içi & $9,5 \%$ & $34,1 \%$ & $37,3 \%$ & $19,0 \%$ &, $0 \%$ & $100,0 \%$ \\
\hline & \multirow{2}{*}{ Özel } & Sayı & 99 & 98 & 60 & 16 & 1 & 274 \\
\hline & & \% sektör içi & $36,1 \%$ & $35,8 \%$ & $21,9 \%$ & $5,8 \%$ &, $4 \%$ & $100,0 \%$ \\
\hline & \multirow{2}{*}{ Toplam } & Sayı & 111 & 141 & 107 & 40 & 1 & 400 \\
\hline & & \% sektör içii & $27,8 \%$ & $35,3 \%$ & $26,8 \%$ & $10,0 \%$ & ,3\% & $100,0 \%$ \\
\hline
\end{tabular}


Tablo 6. Sektör - Yaş Çapraz Tablosu

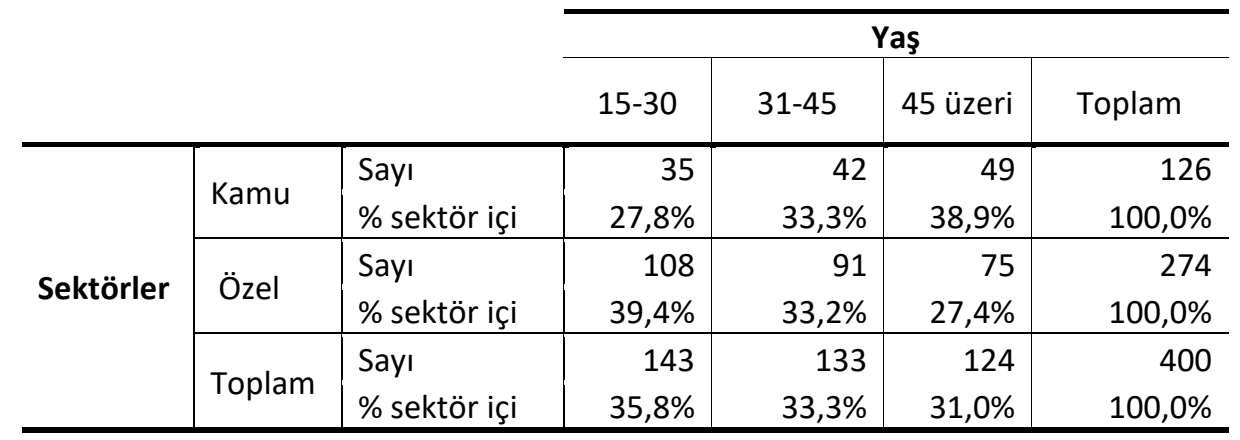

\subsection{Mobil Telefon Kullanımları}

Katılımcıların tamamı mobil telefona sahip olup, sadece 5 kişinin akıllı mobil telefonu bulunmamaktadır. Mobil telefonla internet erişimi olanların oranı \%99,3 tür. Mobil telefonların en fazla internet amacıyla kullanıldığı, internet ile en fazla sosyal medya uygulamaları (\%72) ve haber sitelerinin takip edildiği (\%12) gözlenmiştir. Katılımcıların \%40'ı 3-5 saat, \%29'u 6-10 saat arası ve \%15'i 10 saat üzerinde mobil telefonunu kullandığını belirtmiştir.

Katılımcıların \%56'sı işyerlerinde mobil telefon kullanımı ile ilgili yöneticilerin kısıtlama getirdiğini ancak kısıtlama getirilen çalışanların \%44'ü kısıtlamalara rağmen mobil telefonlarını iş yerlerinde kullandıklarını belirtmişlerdir. Bu sebeple işten atılan çalışana rastlanmamış, ancak katılımcıların \%4'ü iş yerlerinde mobil telefon kullandıkları için sıkıntı yaşamışlardır. Söz konusu sıkıntıları yaşayan çalışanların tamamı özel sektör çalışanı olup \%68'i kadındır.

Çalışanların tamamı kontrol amaçlı dahi olsa mobil telefonlarını işyerlerinde en az bir kere kullanmaktadır. İş yerlerinde mobil telefon kontrol etme süreleri ve sayıları Tablo 7'de verilmiştir. Bu tabloya göre iş saatleri içinde hem kamu hem de özel sektörde kadın çalışanların kişi başı mobil telefonlarını kontrol etme için harcadıkları sürelerin daha fazla olduğu görülmektedir. Kamu sektöründe çalışan kadınlar çalışma süresi içerisinde günde ortalama $24,3 \mathrm{kez}$ mobil telefonlarını kontrol ederken, her bir kontrol etme süresi ortalama 34,3 saniye olarak hesaplanmıştır. Bu değerler özel sektörde çalışan kadınlar için 29,3 kez ve 19,1 saniyedir. Kamu sektöründe çalışma saatleri içerisinde gün boyu mobil telefon kontrolü için harcanan kişi başı ortalama süre 696,34 saniye, özel sektörde 555,64 saniye ve tüm katılımcılar için 625,9 saniyedir. Katılımcıların tamamı temel alındığında, çalışma saatleri içinde mobil telefon kontrolü için çalışan başına ortalama harcanan süre 10,4 dakikadır.

Tablo 7. Kişi Başı Ortalama Mobil Telefon Kontrol Etme Sayıları ve Süreleri

\begin{tabular}{l|c|c|c|c}
\hline \multirow{2}{*}{} & \multicolumn{2}{|c|}{ Kamu sektörü } & \multicolumn{2}{c}{ Özel sektör } \\
\cline { 2 - 5 } & Erkek & Kadın & Erkek & Kadın \\
\hline Kontrol süresi (saniye) & 23,3 & 34,3 & 19,8 & 18,4 \\
\hline Kontrol sayısı & 24 & 24,3 & 23,6 & 35 \\
\hline Kişi başı süre (saniye) & 559,2 & 833,49 & 467,28 & 644 \\
\hline Kişi başı süre (saniye) & \multicolumn{2}{|c|}{696,34} & \multicolumn{2}{c}{555,64} \\
\hline Kişi başı süre (saniye) & \multicolumn{3}{|c}{625,9} \\
\hline
\end{tabular}

\subsection{Faktör ve Regresyon Analiz Bulguları}

Veri toplama aracı ile elde edilen verilere uygulanan faktör analizi sonucuna göre açıklanan varyans değerleri Tablo 8'de sunulmuştur. Fidan (2016) tarafından geliştirilen ölçeğe uygun olarak Varimax döndürme yöntemi ile özdeğeri 1'den büyük olan 5 faktör oluştuğu gözlenmiştir. Tablo 8'e göre faktörler, toplam varyansın \%63,2'sini açıklamaktadır. Oluşan faktörler ve faktör yükleri Tablo 9'da verilmiştir. 
Tablo 8. Açıklanan Toplam Varyans

\begin{tabular}{l|r|r|r|r|r|r}
\hline \multirow{2}{*}{ Bileşen } & \multicolumn{3}{|c|}{ Özdeğerler } & \multicolumn{3}{c}{ Döndürülen Yüklerin Kareler Toplamı } \\
\cline { 2 - 7 } & \multicolumn{1}{|c|}{ Toplam } & \multicolumn{1}{c|}{ \%Varyans } & \multicolumn{1}{c|}{ \%Kümülatif } & \multicolumn{1}{c}{ Toplam } & \multicolumn{1}{c}{ \%Varyans } & \%Kümülatif \\
\hline 1 & 6,237 & 34,649 & 34,649 & 2,969 & 16,492 & 16,492 \\
2 & 1,557 & 8,650 & 43,299 & 2,761 & 15,340 & 31,832 \\
3 & 1,468 & 8,157 & 51,456 & 2,131 & 11,839 & 43,671 \\
4 & 1,126 & 6,256 & 57,712 & 1,961 & 10,893 & 54,564 \\
$\mathbf{5}$ & $\mathbf{1 , 0 0 5}$ & $\mathbf{5 , 5 8 4}$ & $\mathbf{6 3 , 2 9 6}$ & $\mathbf{1 , 5 7 2}$ & $\mathbf{8 , 7 3 1}$ & $\mathbf{6 3 , 2 9 6}$ \\
6 &, 844 & 4,689 & 67,985 & & & \\
7 &, 768 & 4,267 & $\mathbf{7 2 , 2 5 2}$ & & & \\
8 &, 714 & 3,965 & $\mathbf{7 6 , 2 1 7}$ & & & \\
\hline
\end{tabular}

Tablo 9. Faktör Yükleri

\begin{tabular}{l|l|l|l|l|l}
\hline & \multicolumn{5}{|c}{ Bileşenler } \\
\hline & 1 & 2 & 3 & 4 & 5 \\
\hline TOL4 &, 776 & & & & \\
TOL2 &, 766 & & & & \\
TOL1 &, 708 & & & & \\
TOL3 &, 650 & & & & \\
UZ1 & &, 780 & & & \\
UZ2 & &, 773 & & & \\
UZ3 & &, 669 & & & \\
int3 & & &, 765 & & \\
int1 & & &, 738 & & \\
int4 & & &, 637 & & \\
int2 & & &, 601 & & \\
BEL3 & & & &, 783 & \\
BEL2 & & & &, 676 & \\
BEL4 & & & &, 612 & \\
BEL1 & & & &, 507 & \\
TEK3 & & & & &, 809 \\
TEK1 & & & & &, 653 \\
TEK2 & & & & &, 596 \\
\hline
\end{tabular}

Faktörlere göre mobil bağımlıı̆ın belirlenmesi için kullanılacak matematiksel fonksiyonu elde etmek için doğrusal regresyon analizi kullanımıştır. Regresyon analizine göre elde edilen katsayı değerleri Tablo 10 ve bu katsayılara göre oluşturulan matematiksel denklem aşağıda verilmiştir.

Tablo 10. Regresyon Katsayıları

\begin{tabular}{l|r|r|r}
\hline & \multicolumn{1}{|c|}{ B } & \multicolumn{1}{c|}{ t } & \multicolumn{1}{c}{ p } \\
\hline Sabit & 2,739 & 2581,791 &, 000 \\
Tolerans (TOL) &, 405 & 381,291 &, 000 \\
Uzaklaşım (UZ) &, 403 & 379,192 &, 000 \\
Mobil İnternet Eğilimi (INT) &, 284 & 267,006 &, 000 \\
Belirginlik (BEL) &, 287 & 270,346 &, 000 \\
Tekrarlama (TEK) &, 234 & 220,009 &, 000 \\
\hline
\end{tabular}

$m \_b=2,739+0,405 * T O L+0,403 * U Z+0,284 * I N T+0,287 * B E L+0,234 * T E K$ 
Denkleme göre mobil bağımlılık tanısının konulabilmesi için kullanılan likert ölçeğine uygun olarak Tablo 11'deki gibi bir sınıflama yapılmıştır. Faktörleşen değişkenlere verilen cevapların ortalamaları ile elde edilen faktör değerleri, regresyon ifadesinde kullanılarak $m \_b$ değerleri hesaplanmıştır. Tablo 11'e göre $m \_b$ değerinin 9,191 den büyük olduğu durumlarda mobil bağımlılık tanısı konulabilmektedir. Mobil bağımlııı eğilimi ise 7,578-9,191 aralığındaki m_b değeri ile belirlenebilir.

Tablo 11. Mobil Bağımlılık Tanı Değerleri

\begin{tabular}{l|l|l|l}
\hline \multicolumn{1}{c|}{ Kullanım durumu } & $\begin{array}{c}\text { Faktör } \\
\text { değerleri }\end{array}$ & Mobil bağımlılık tanı değeri & \multirow{2}{*}{ Bağımlılık değerlendirme } \\
\cline { 1 - 3 } En alt düzey kullanım & 1 & $2,739<=m \_b<=4,352$ & \multirow{2}{*}{ Bağımlılık yok } \\
\cline { 1 - 3 } Düşük düzey kullanım & 2 & $4,352<m \_b<=5,965$ & \\
\cline { 1 - 3 } Normal kullanım & 3 & $5,965<m \_b<=7,578$ & Bağımlılık eğilimi \\
\hline Bağımlılık eğilimi & 4 & $7,578<m \_b<=9,191$ & Mobil bağımlı \\
\hline Mobil Bağımlı & 5 & $9,191<m \_b<=10,804$ & \\
\hline
\end{tabular}

Regresyon ifadesine göre katılımcıların cevapları değerlendirilmiş ve hesaplanan $m \_b$ değerlerine göre 24 çalışan mobil bağımlı, 127 çalışanda mobil bağımlılık eğilimi olmak üzere toplam 151 katılımcıda mobil bağımlılık sorunu olduğu belirlenmiştir. Mobil bağımlılık oranlarının verildiği Tablo 12' de mobil bağımlılık ve eğiliminin tüm katılımcılar içerisindeki oranı sırasıyla \%6 ve \% 31,75'tir. Mobil bağımlılık eğiliminin özel sektörde daha yüksek olmasına karşın bağımlılı̆ın kamu sektöründe daha yüksek olduğu görülmektedir. Kamu sektöründe mobil bağımlılık oranı $\% 8,8$ ve özel sektörde $\% 5,2$ 'dir.

Tablo 12. Mobil Bağımlılık Oranları

\begin{tabular}{|c|c|c|c|c|c|c|}
\hline & \multirow{2}{*}{$\begin{array}{l}\text { Bağımlılığı } \\
\text { olmayan }\end{array}$} & \multirow{2}{*}{$\begin{array}{l}\text { Bağımlılık } \\
\text { eğilimi }\end{array}$} & \multirow{2}{*}{$\begin{array}{l}\text { Mobil } \\
\text { bağımlı }\end{array}$} & \multirow[t]{2}{*}{ Toplam } & \multicolumn{2}{|c|}{ Sektör içindeki oranı } \\
\hline & & & & & Eğilimli & Bağımlı \\
\hline Kamu sektörü & 51 & 21 & 7 & 79 & $\% 26,5$ & $\% 8,8$ \\
\hline Özel Sektör & 198 & 106 & 17 & 321 & $\% 33$ & $\% 5,2$ \\
\hline Toplam & 249 & 127 & 24 & 400 & & \\
\hline $\begin{array}{l}\text { Katılımcılar } \\
\text { içindeki oranı }\end{array}$ & $\% 62,25$ & $\% 31,75$ & $\% 6$ & & & \\
\hline
\end{tabular}

Tablo 13'te verilen Anova test sonuçları, mobil bağımlılığında yaş, cinsiyet, gelir, sektör ve eğitim seviyesine göre anlamlı farklılıklar göstermediği, farklılıkların kullanım süresi, mobil telefon kontrol sayısı ve kontrol süresi değişkenleri ile ilgili olduğu tespit edilmiştir.

Tablo 13. Mobil Bağımlılık Anova Test Sonuçları

\begin{tabular}{|c|c|c|c|c|c|c|}
\hline \multicolumn{2}{|c|}{ Değişkenler } & $\begin{array}{l}\text { Kareler } \\
\text { toplamı }\end{array}$ & $\begin{array}{l}\text { Serbestlik } \\
\text { (df) }\end{array}$ & $\begin{array}{c}\text { Ortalama } \\
\text { kareler }\end{array}$ & $\mathbf{F}$ & p \\
\hline Yaş & $\begin{array}{l}\text { Gruplar arası } \\
\text { Grup içi } \\
\text { Toplam }\end{array}$ & $\begin{array}{r}\text {,003 } \\
210,995 \\
210,997\end{array}$ & $\begin{array}{r}1 \\
398 \\
399 \\
\end{array}$ & $\begin{array}{r}, 003 \\
, 530\end{array}$ & ,005 & ,944 \\
\hline Gelir & $\begin{array}{l}\text { Gruplar arası } \\
\text { Grup içi } \\
\text { Toplam }\end{array}$ & $\begin{array}{r}, 001 \\
218,296 \\
218,298 \\
\end{array}$ & $\begin{array}{r}1 \\
398 \\
399 \\
\end{array}$ & $\begin{array}{l}, 001 \\
, 548\end{array}$ & ,002 & ,961 \\
\hline Eğitim & $\begin{array}{l}\text { Gruplar arası } \\
\text { Grup içi } \\
\text { Toplam }\end{array}$ & $\begin{array}{r}, 956 \\
431,842 \\
432,797 \\
\end{array}$ & $\begin{array}{r}1 \\
398 \\
399 \\
\end{array}$ & $\begin{array}{r}, 956 \\
1,085\end{array}$ & 881 & ,349 \\
\hline Sektör & $\begin{array}{l}\text { Gruplar arası } \\
\text { Grup içi } \\
\text { Toplam }\end{array}$ & $\begin{array}{r}, 035 \\
63,362 \\
63,397\end{array}$ & $\begin{array}{r}1 \\
398 \\
399 \\
\end{array}$ & $\begin{array}{l}, 035 \\
, 159\end{array}$ & ,222 & ,638 \\
\hline
\end{tabular}


Tablo 13. Mobil Bağımlılık Anova Test Sonuçları (devam)

\begin{tabular}{|c|c|c|c|c|c|c|}
\hline \multicolumn{2}{|c|}{ Değişkenler } & $\begin{array}{l}\text { Kareler } \\
\text { toplamı }\end{array}$ & $\begin{array}{l}\text { Serbestlik } \\
\text { (df) }\end{array}$ & $\begin{array}{c}\text { Ortalama } \\
\text { kareler }\end{array}$ & $\mathbf{F}$ & $\mathbf{p}$ \\
\hline Kullanım süresi & $\begin{array}{l}\text { Gruplar arası } \\
\text { Grup içi } \\
\text { Toplam }\end{array}$ & $\begin{array}{r}58,159 \\
318,279 \\
376,438\end{array}$ & $\begin{array}{r}1 \\
398 \\
399\end{array}$ & $\begin{array}{r}58,159 \\
, 800\end{array}$ & 72,726 & ,000 \\
\hline Cinsiyet & $\begin{array}{l}\text { Gruplar arası } \\
\text { Grup içi } \\
\text { Toplam }\end{array}$ & $\begin{array}{r}, 030 \\
99,068 \\
99,098\end{array}$ & $\begin{array}{r}1 \\
398 \\
399 \\
\end{array}$ & $\begin{array}{l}\text {,030 } \\
\text {,249 }\end{array}$ & 120 & ,730 \\
\hline Kontrol süresi & $\begin{array}{l}\text { Gruplar arası } \\
\text { Grup içi } \\
\text { Toplam }\end{array}$ & $\begin{array}{r}2793,336 \\
260278,602 \\
263071,938 \\
\end{array}$ & $\begin{array}{r}1 \\
398 \\
399 \\
\end{array}$ & $\begin{array}{r}2793,336 \\
653,966\end{array}$ & 4,271 & ,039 \\
\hline Kontrol sayısı & $\begin{array}{l}\text { Gruplar arası } \\
\text { Grup içi } \\
\text { Toplam }\end{array}$ & $\begin{array}{r}45073,589 \\
1779637,411 \\
1824711,000\end{array}$ & $\begin{array}{r}1 \\
398 \\
399 \\
\end{array}$ & $\begin{array}{r}45073,589 \\
4471,451\end{array}$ & 10,080 & ,002 \\
\hline
\end{tabular}

Tablo 14'te ise mobil bağımlı olmayan ve bağımlılık tanısı konulan çalışanların sektör ve cinsiyetlere göre çalışma saatleri içinde kişi başı ortalama mobil telefon kontrol etme sayıları ve süreleri verilmiştir. Tablo 7'de yer alan değerlere göre karşılaştıııldığında, mobil bağımlı olarak belirlenen çalışanların kişi başı ortalama mobil telefon kontrol etme sürelerinin yüksek olduğu, mobil bağımlı olmayanların ise düşük olduğu görülmüştür. Ayrıca mobil bağımlı olan çalışanların, mobil bağımlı olmayan çalışanlara nazaran mobil telefon kontrolü için yaklaşık 4 kat daha fazla zaman harcamaktadırlar. Bu durum, mobil bağımlılığı olan kişilerin daha sık ve uzun süre mobil telefonlarını kontrol ettiklerini ortaya koymaktadır. Tablo 7'de tüm katılımcılar için, mobil telefonu çalışma saatleri içinde kontrol etme için kişi başı harcanan ortalama süre 10,4 dakika iken bu değer Tablo 14'te 25,4 dakika (1529 saniye) olarak hesaplanmıştır. Mobil bağımlılığın sebep olduğu mobil telefon kontrol etme isteğinin, kişi başı ortalama iş kaybı süresini gösteren bu değer, kamu sektöründe 1587 saniye (26,4 dakika) ve özel sektörde 1471,1 saniyedir (24,5 dakika). Bir günlük çalışma süresinin 480 dakika olduğu düşünüldüğünde, mobil telefon kontrol etmek için harcanan süre, mobil bağımlılığı olan kamu sektöründeki 18 çalışan ve özel sektördeki 20 çalışan, bir kişinin günlük mesaisine karşılık gelmektedir. Başka bir deyişle mobil bağımlı 18 çalışan, kamu kurumuna süre açısından bir çalışan maliyet getirmektedir.

Tablo 14. Kişi Başı Ortalama Mobil Telefon Kontrol Etme Süre ve Sayıları

\begin{tabular}{l|c|c|c|c|c|c|c|c}
\hline & \multicolumn{4}{|c|}{ Mobil bağımlı çalışanlar } & \multicolumn{3}{c}{ Mobil bağımlı olmayan çalışanlar } \\
\hline & Kamu sektörü & \multicolumn{2}{|c|}{ Özel sektör } & \multicolumn{2}{c}{ Kamu sektörü } & \multicolumn{2}{c}{ Özel sektör } \\
\hline & Erkek & Kadın & Erkek & Kadın & Erkek & Kadın & Erkek & Kadın \\
\hline Kontrol süresi (saniye) & 32,2 & 36,2 & 34,7 & 37,1 & 21,3 & 24,2 & 15,7 & 16,4 \\
\hline Kontrol sayısı & 43,6 & 48,9 & 35,4 & 46,2 & 20 & 18,7 & 18,3 & 23,6 \\
\hline Kişi başı süre (saniye) & 1403,9 & 1770,1 & 1228,3 & 1714 & 426 & 452,5 & 287,3 & 387 \\
\hline Kişi başı süre (saniye) & \multicolumn{3}{|c|}{1587} & \multicolumn{3}{|c|}{1471,1} & \multicolumn{4}{c}{439,2} & 337 \\
\hline Kişi başı süre (saniye) & \multicolumn{1}{|c|}{1529} & \multicolumn{4}{c}{388,1} \\
\hline
\end{tabular}

\section{Tartışma ve Öneriler}

Kamu ve özel sektör çalışanlarının, işyerlerinde mobil telefon kullanım ve mobil bağımlılık düzeylerinin araştıııldığı çalışmada 400 katılımcıdan elde edilen anket verileri analiz edilmiştir. Araştırma sonucunda elde edilen (1) nolu denklemdeki regresyon ifadesi kullanılarak çalışanların mobil bağımlılık düzeyleri hesaplanmış ve 24 çalışanın mobil bağımlı olduğu belirlenmiştir. Bu değer katılımcılar içerisinde mobil bağımlılık düzeyinin \%6 olduğu anlamına gelmektedir. Ayrıca çalışanlar arasında mobil bağımlılığın cinsiyet, yaş, gelir, eğitim düzeyi ve sektöre göre anlamlı farklılıkların olmadığı belirlenmiştir. Başka bir deyişle demografik, sosyal ve sektörel açıdan farklılıklara sahip tüm çalışanlar risk grubundadır. Diğer taraftan mobil bağımlılık ile mobil telefon kullanım süresi, kontrol etme sayısı ve kontrol etme süresi arasında anlamlı 
farklılıklar belirlenmiştir. Bu değişken değerlerinin artması mobil bağımlılık düzeyinin de artması anlamına gelmektedir. Tablo 14'de görüleceği üzere, bu değerlerin yüksek olduğu kamu sektöründe, mobil bağımlılık riski daha yüksektir. Cinsiyetlere göre ise hem kamu hem de özel sektörde çalışan kadınların bağımlılık risklerinin yüksek olduğu görülmektedir. Mobil bağımlılığı olan kamu çalışanlarının mesai saatleri içerisinde mobil telefonlarını kontrol etmelerinden kaynaklanan kişi başı iş kaybı süresi 26,4 dakika, özel sektörde 24,5 dakikadır. Bu değerler tüm katılımcılar düşünüldüğünde kamu sektöründe 11,6 dakika ve özel sektörde 9,2 dakika iken mobil bağımlılığı olmayan kamu çalışanlarında 7,3 dakika ve özel sektör çalışanlarında 5,6 dakikadır.

Özel sektörde, çalışanlar arasında mobil bağımlılık oranının daha düşük olmasına karşın, mobil bağımlıık eğilimi kamu sektörüne nazaran daha yüksektir. İlerleyen süreçlerde çalışanların mobil bağımlı olma riskinin yüksek olacağı anlamına gelen bu durum, özel sektör firmaları tarafından dikkate alınmalıdır. Özel sektörde çalışan her üç kişiden birinin mobil bağımlılık eğilimine sahip olması, durumun ciddiyetini ortaya koymaktadır.

Mobil telefon kullanımlarının firmalara verdiği iş kaybı, güvenlik ve işyeri nedeniyle, firmalar genellikle kısıtlama ve yasaklama işlemleri uygulamaktadır (Marius, 2016). Güvenlik nedenleriyle Beyaz Saray çalışanlarının mobil telefon kullanımı yasaklanmıştır (Jacobs, 2018). Avustralya'da işyeri verimliliğini azalttığından dolayı çalışanların iş saatleri içinde mobil telefon kullanımları yasaklanmış ve çalışan verimliliğinde yükselme belirlenmiştir (Beattie, 2016). Bazı firmalar, işyerlerinde çalışanların yanı sıra müşterilerinin mobil telefon kullanımlarını da yasaklamaktadır (NTV, 2017). Ayrıca bu uygulamalar hukuki açıdan da desteklenmektedir (Bkz: Yargıtay 9. Hukuk Dairesi de 2007/27583 E, 2008/5294 K). Ancak, araştırma sonuçlarına göre katıımcıların \% 44 'ü firma kısıtlama ve yasaklamalarına rağmen iş yerinde mobil telefon kullandıklarını ve bu uygulamaların etkili olmadığını ifade etmişlerdir. Ancak neden olduğu iş kaybı düşünüldüğünde, firmalar tarafından önlem alınması gereken bir sorun olduğu açıktır. Çalışanların mobil bağımlıık ile ilgili bilgilendirilmeleri, bu konuda destek eğitimlerinin verilmesi ve çalışanların bilinçlendirilmesi çözüm olarak düşünülebilir.

Kamu ve özel sektör çalışanlarının mobil bağımlılık düzeylerinin analizinin gerçekleştirildiği bu çalışma, sektörlerdeki çalışma kolları veya belirli bir firma hedef alınarak yenilenebilir. Ayrıca Tablo 6 'da görüldüğü üzere düşük yaş seviyelerinde mobil telefon kullanım düzeyleri artmaktadır. Bu tablo, genç nüfusu hedef alan mobil bağımlııık üzerine araştırmaların yapılması gerektiğini göstermektedir. Bu araştırma kapsamı dışında tutulan 15 yaş altı gençlerin mobil bağımlıık düzeylerinin belirlenmesi gelecek çalışmalarda gerçekleştirilebilir.

\section{Sonuç}

Sosyal hayat ve iş hayatına getirdiği imkânlar ile kullanımları yaygınlaşan bilişim teknolojileri, sağladığı avantajların yanı sıra bazı sorunları da yol açmaktadır. Son yıllarda davranışsal bağımlıık kapsamında incelenen teknolojik bağımlılık, bilişim teknolojilerinin aşırı kullanımlarından kaynaklanan toplumsal bir sorun olarak görülmektedir (Fidan, 2016; Griffiths, 2005). Sosyal hayat içerisinde en yaygın kullanım oranlarına sahip olan ve insanların her an yanında taşıyabilecekleri mobil telefonlar, bağımlılık riskinin en yüksek olduğu elektronik cihazlardır.

Firmaların sahip oldukları teknolojik alt yapı gereği, teknolojik cihazları kullanmak zorunda olan çalışan kesim, bağımlılık kavramı ile karşı karşıyadır. Çalışanların iş motivasyonlarının ve iş verimliliklerinin azalmasına sebep olan mobil bağımlılık firmalarda iş kaybına neden olmaktadır. Literatürde yeterince yoğunlaşılmayan çalışanlar arasındaki mobil telefon kullanım ve bağımlılık düzeyleri bu çalışmada analiz edilmiş, özel ve kamu sektörü çalışanlarının mobil telefon kullanım ve bağımlıık düzeyleri tespit edilmiştir.

Araştırma istatistiki bölge birimleri TR61 bölgesinde yer alan Burdur, Isparta ve Antalya illerinde kamu ve özel sektör çalışanları ile gerçekleştirilmiştir. Bu kapsamda "Mobil Bağımlılık Ölçeği” ile 400 katılımcıdan elde edilen veriler kullanılarak faktör ve regresyon analizleri gerçekleştirilmiştir. Regresyon denklemi ve faktör değişken değerleri kullanılarak mobil bağımlılık tanı aralıkları hesaplanmış ve bu aralık değerleriyle kullanıcıların mobil bağımlılık düzeyleri belirlenmiştir. Söz konusu düzeylere göre 24 katılımcının mobil 
bağımlı, 127 katılımcının mobil bağımlılık eğilimine sahip olduğu belirlenmiştir. Bu değerler çalışanlar arasında mobil bağımlııı oranının \%6, mobil bağımlılığa eğilimi olanların oranının \%31,75 olduğu anlamına gelmektedir.

Mobil bağımlılı̆ın yaş, cinsiyet, gelir düzeyi, sektör ve eğitim düzeyi farklııkları ile anlamlı bir ilişkisi yoktur. Başka bir deyişle her yaş, cinsiyet, gelir, eğitim düzeyi ve sektörden çalışanlar mobil bağımlılık riski altındadır. Çalışma, iş yerlerinde çalışma saatleri içinde mobil telefon kontrol etme sayısı ve süresinin, mobil bağımlı olan çalışanlarla anlamlı ilişkisi olduğunu ortaya koymaktadır. Kamu sektöründe çalışanların mobil telefonlarını kontrol etme sayı ve süresi, özel sektör çalışanlarına nazaran yüksektir. Bu durum kamu sektörü çalışanlarının mobil bağımlıık risklerinin yüksek olduğunu göstermektedir. Ayrıca bu sebepten dolayı iş saatleri içerisinde kişi başı harcanan ortalama süre kamu sektöründe 26,4 dakikadır. Bu değer mobil bağımlılığı olan 18 kişinin çalıştığı bir kamu kurumunda, 1 kişinin günlük mesai süresine karşlık gelmektedir.

İşyeri sahiplerinin, mobil telefon kullanımlarında yasaklama ve kısıtlamaya gidilmesinin verimliliği arttırdığı düşünülse de, araştırmaya katılan çalışanların \%44'ü kısıtlama ve yasaklamaların mobil telefon kullanımlarını etkilemeyeceğini belirtmişlerdir. Başka bir deyişle işyerlerinde mobil telefon kullanımlarının kısıtlanması veya tamamen yasaklanması çalışanlar açısından sorunun çözümü olarak görülmemektedir. Bunun yerine firmaların durum tespiti yapmaları ve çalışanlarını bilinçlendirici yaklaşımlarda bulunmaları sorunun çözümü bağlamında daha önemlidir.

\section{Kaynaklar}

APA (2013). Highlights of changes from DSM-IV-TR to DSM-5. http://www.dsm5.org/Documents/changes\%20from\%20dsm-iv-tr\%20to\%20dsm-5.pdf (Erişim Tarihi, 23 Mayıs 2017).

Beattie, A. (2016). Australian workplaces ban smartphones and boost productivity. Huffposy, https://www.huffingtonpost.com.au/2016/01/15/phone-ban-workplace_n_8975828.html (Erişim Tarihi: 14 Nisan 2018).

Bianchi, A., \& Phillips, J. G. (2005). Psychological predictors of problem mobile phone use. CyberPsychology \& Behavior, $8(1), 39-51$.

Billieux, J., Vander-Linden, M., \& Rochat, L. (2008). The role of impulsivity in actual and problematic use of the mobile phone. Appl Cogn Psychol, 22(9), 1195-210.

Billieux, J., Maurage, P., Fernandez, O. L., Kuss, D. J., \& Griffiths, M. D. (2015). Can disordered mobile phone use be considered a behavioral addiction? An update on current evidence and a comprehensive model for future research. Current Addiction Reports, 2(2), 156-162.

Bozeman, M. (2011, July 27). Smartphone obsession the latest addiction. Bozeman Daily Chronicle.

Butler, E.S., Asaheim, C., \& Williams, S. (2007). Does telecommuting improve productivity?. Communications of the ACM, 50(4), 101-103.

CareerBuilder (2016). New CareerBuilder survey reveals how much smartphones are sapping Productivity at work. http://www.careerbuilder.com/share/aboutus/pressreleasesdetail.aspx?sd=6\%2F9\%2F2016\&id=pr954\&ed=12 \%2F31\%2F2016 (Erişim Tarihi, 10 Nisan 2018).

Choliz, M. (2012). Mobile-phone addiction in adolescence: The test of mobile phone dependence (TMD). Prog Health Sci, 2(1), 33-44.

CNBC (2011). Marc Andreessen is bullish on the economy. http://www.cnbc.com/id/47244961 (Erişim Tarihi, 01 Mayıs 2017).

Fidan, H. (2016). Mobil bağımlılık ölçeği'nin geliştirilmesi ve geçerliliği: Bileşenler modeli yaklaşımı. Addicta, (3), 433469.

Fidan, H. (2017). Türkiye'de sektörel eşitsizlikler ve sayısal bölünme ilişkisi. Sosyoekonomi, 25(32), 31-50.

Fitchard, K. (2013). Ericsson: Global smartphone penetration will reach $60 \%$ in 2019, https://gigaom.com/2013/11/11/ericsson-global-smartphone-penetration-will-reach-60-in-2019/ (Erişim Tarihi, 11 Mayıs 2017). 
İşyerlerinde Mobil Telefon Kullanım ve Bağımlıık Düzeyleri: Kamu ve Özel Sektör Çalışanları Üzerine Bir Araştırma

Fortune (2017). Here's how you're wasting 8 hours per work week. http://fortune.com/2017/07/25/cell-phone-lostproductivity/ (Erişim Tarihi: 10 Nisan 2018).

Griffiths, M. (1995). Technological addictions. Clinical Psychology Forum, 14-19.

Griffiths, M. (2005). A compenent model of addiction within a biopsychosocial framework. Journal of Substance Use, 10(4), 191-197.

Hilbrecht, M., Shaw, S.M., Johnson, L.C., \& Andrey, J. (2008). I'm home for the kids:contradictory implications for worklife balance of teleworking mothers. Gender, Work and Organisation, 5(15), 455-471.

ITU (2015). ICT Facts \& Figures 2015. http://www.itu.int/en/ITU-D/Statistics/Pages/facts/default.aspx (Erişim Tarihi, 11 Mayıs 2017).

IHH (2015). Teknoloji kullanımı ve bağımlılığı açısından Türkiye gençliğinin fotoğrafı. Sakarya Üniversitesi İnsani ve Sosyal Araştırmalar Merkezi Uluslararası Doktorlar Birliği, http://insamer.com/wp-content/uploads/2015/03/TeknolojiBagimliligi....pdf (Erişim Tarihi, 21 Haziran 2016).

Jacobs, J. (2018). White House bans staff from using personal mobile phones at work. Bloombergpolitics, https://www.bloomberg.com/news/articles/2018-01-04/a-new-ban-at-the-white-house-staff-s-personalmobile-phones (Erişim Tarihi: 14 Nisan 2018).

Karim, R., \& Chaudhri, P. (2012). Behavioral addictions: An overview. Journal of Psychoactive Drugs, 44(1), 5-17.

Knutson, B., Rick, S., Wimmer, G.E., Prelec, D., \& Loewenstein, G. (2007). Neural predictors of purchases. Neuron, 53, 147-56.

Ko, C. H., Liu, G. C., Hsiao, S., Yen, J. Y., Yang, M. J., Lin, W. C., Yen, C. F., \& Chen, C. S. (2009). Brain activities associated with gaming urge of online gaming addiction. Journal of Psychiatric Research, 43(7), 739-747.

Kootstra, G. J. (2004). Exploratory Factor Analysis: Theory and application, http://www.let.rug.nl/nerbonne/teach/rema-stats-meth-seminar/Factor-Analysis-Kootstra-04.pdf (10 Mart 2017).

Kuss, D. J., Shorter, G. W., Rooij, A. J., Griffiths, M. D., \& Schoenmakers, T. M. (2013). Assessing internet addiction using the parsimonious internet addiction components model: A preliminary study. International Journal of Mental Health and Addiction, 12(3), 351-366.

Kwon, M., Lee, J. Y., Won, W. Y., Park, J. W., Min, J. A., \& Hahn, C. (2013). Development and validation of a smartphone addiction scale (SAS). PLoS One, 8(2), 1-7.

Leshner, A. (1997). Addiction is a brain disease, and it matters. Science, 278(5335), 807-808.

Lewis, S., \& Cooper, C. L. (2005). Work-life integration. Chichester: Wiley.

Marius, M. (2016). Should mobile/cell phones be banned in the workplace? ICTpulse, http://www.ictpulse.com/2016/07/mobilecell-phones-banned-workplace/ (Erişim Tarihi: 14 Nisan 2018).

Marlatt, G. A., Baer, J. S., Donovan, D. M., \& Kivlahan, D. R. (1988). Addictive behaviors: Etiology and treatment. Annual Review of Psychology, 39, 223-252.

Mcllwraith, R., Jacobvitz, R. S., Kubey, R., \& Alexander, A. (1991). Television addiction: Theories and data behind the ubiquitous metaphor. American Behavioral Scientist, 35, 104-121.

Merlo, L. J., Stone, A. M., \& Bibbey, A. (2013). Measuring problematic mobile phone use: Development and preliminary psychometric properties of the PUMP scale. Hindawi Publishing Corporation Journal of Addiction, 2013(912807), http://dx.doi.org/10.1155/2013/91280

Miller, G. (2012). The smartphone psychology manifesto. Perspectives on Psychological Science, 7(3), $221-237$.

NTV (2017). Bu restoranda cep telefonu yasak. https://www.ntv.com.tr/dunya/bu-restoranda-cep-telefonuyasak,fHIMqripQUmheoTm_LOPag (Erişim Tarihi: 14 Nisan 2018).

OfficeTeam (2017). Working ard or hardly working? Employees waste more than one day a week on non-work activities. http://rh-us.mediaroom.com/2017-07-19-WORKING-HARD-OR-HARDLY-WORKING-Employees-Waste-MoreThan-One-Day-a-Week-on-Non-Work-Activities. (Erişim Tarihi: 12 Nisan 2018).

Park, W. (2005). Mobile phone addiction. Mobile Communications, 31, 253-272.

Pitichat, T. (2013). Smartphones in the workplace: Changing organizational behavior, transforming the future. LUX: $A$ Journal of Transdisciplinary Writing and Research from Claremont Graduate University, 3(1), Article 13.

Polat, Y. (2012). Faktör analizi yöntemlerinin karşılaştırmalı olarak incelenmesi ve hayvancılık denemesine uygulanışı. Çukurova Üniversitesi Fen Bilimleri Enstitüsü, Doktora Tezi, Adana. 
Randstad (2015). Basın bülteni. https://www.randstad.com.tr/reports/randstad-workmonitor/randstad-workmonitorisverenler-mesai-disinda-da-calisanlarina-ulasmak-istiyor.pdf (Erişim Tarihi, 20 Ocak 2018).

Reid, D. J., \& Reid, F. J. M. (2007). Text or talk? Social anxiety, loneliness, and divergent preferences for cell phone use, CyberPsychology and Behavior, 10(3), 424-435.

Salehan, M., \& Negahban, A. (2013). Social networking on smartphones: When mobile phones become addictive. Computers in Human Behavior, 29, 2632-2639.

Sang, K. J. C., Gyi, D. E., \& Haslam, C. (2010). Musculoskeletal symptoms in pharmaceutical sales representatives. Occupational Medicine, 60(2), 108-114.

Shaffer, H. J., LaPlante, D. A., LaBrie, R. A., Kidman, R. C., Donato, A. N., \& Stanton, M. V. (2004). Towards a syndrome model of addiction: Multiple expressions, common etiology. Harvard Review of Psychiatry, 12, 1-8.

Smith, R. (1986). Television addiction. In J. Bryant, D. Zillmann (Eds.), Perspectives on media effects. Hillsdale, NJ: Lawrence Erlbaum Associates, 109-128.

Statista (2016). Mobile phone users worldwide 2013-2019, https://www.statista.com/statistics/274774/forecast-ofmobile-phone-users-worldwide/ (Erişim Tarihi, 06 Ağustos 2017).

Sultan, A. J. (2014). Addiction to mobile text messaging applications is nothing to "Iol" about, The Social Science Journal, $51,57-69$.

Tabachnick, B. G., \& Fidell, L. S. (2013). Using multivariate statistics, 6th Edition, USA: Pearson Publishing.

The Economist. (2012). Slaves to the smartphone. The Economist, 402, 80-n/a.

Toda, M., Ezoe, S., Nishi, A., Mukai, T., Goto, M., \& Morimoto, K. (2008). Mobile phone dependence of female students and perceived parental rearing attitudes. Social Behavior and Personality, 36(6), 765-770.

Turel, O., Serenko, A., \& Giles, P. (2011). Integrating technology addiction and use: An empirical investigation of online auction users. MIS Quarterly, 35(4), 1043-1061.

Tüik (2017). Nüfus istatistikleri. http://www.tuik.gov.tr, (Erişim Tarihi, 05 Haziran 2017).

Vitak, J., Crouse, J., \& LaRose, R. (2011). Personal internet use at work: Understanding cyberslacking. Computers in Human Behavior, 27(5), 1751-1759.

Wahla, R. S., \& Awan, A. G. (2014). Mobile phones usage and employees' performance: A perspective from Pakistan. International Journal of Academic Research in Accounting, Finance and Management Sciences, 4(4), $153-165$.

Wang, G. J., Volkow, N. D., Thanos, P. K., \& Fowler, J. S. (2004). Similarity between obesity and drug addiction as assessed by neurofunctional imaging: A concept review. Journal of Addictive Diseases, 23(3), 39-53.

Wheatley, D. (2012). Good to be home? Time use and satisfaction levels among home-based teleworkers, New Technology, Work \& Employment, 27(3), 224-241.

Yen, C. F., Tang, T. C., Yen, J. Y., Lin, H. C., Huang, C. F., Liu, S. C., \& Ko, C. H. (2009). Symptoms of problematic cellular phone use, functional impairment and its association with depression among adolescents inSouthern Taiwan. Journal of Adolescence, 32(3), 863-873.

Yihong, Y., Raubal, M., \& Liu, Y. (2010). Correlating mobile phone usage and travel behavior: A case study of Harbin, China. Computers, Environment and Urban Systems, 36(2), March 2012, pp. 118-130.

Young, K. S. (2007). Cognitive behavior therapy with internet addicts: Treatment outcomes and implications. Cyberpsychology \& Behavior, 10(5), 671-679.

Zielinski, D. (2012). Bring your own device. HR Magazine, 71-74.

Zimmerman, K. (2017). Is your cell phone killing your productivity at work? https://www.forbes.com/sites/kaytiezimmerman/2017/03/26/is-your-cell-phone-killing-your-productivity-atwork/\#53122269605c (Erişim Tarihi: 10 Nisan 2018). 
This Page Intentionally Left Blank 